\title{
Pollution level and Source of Cd in Jiaozhou Bay
}

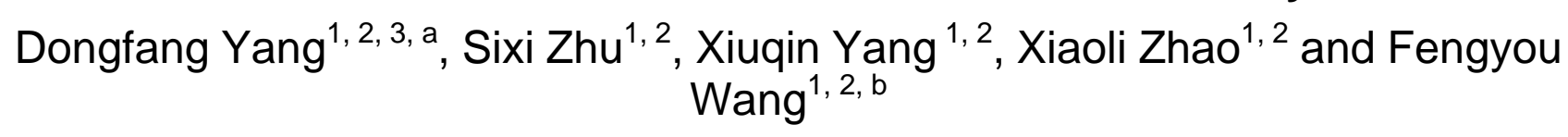

${ }^{1}$ Research Center for Karst Wetland Ecology, Guizhou Minzu University, Guiyang 550025, China;

${ }^{2}$ College of Chemistry and Environmental Science, Guizhou Minzu University, Guiyang 550025, China;

${ }^{3}$ North China Sea Environmental Monitoring Center, SOA, Qingdao 266033, China.

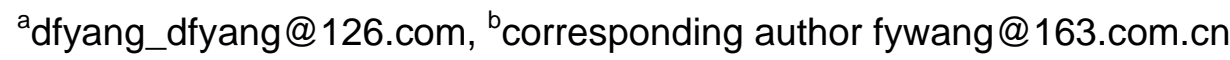

Keywords: Cd; Content; Pollution level; Source; Jiaozhou Bay

\begin{abstract}
This paper analyzed the content, pollution level, distribution and source of Cd in surface waters in Jiaozhou Bay in 1983. Results showed that Cd contents in May, September and October ranged from $0.09-0.41 \mu \mathrm{g} \mathrm{L}^{-1}, 0.40-3.33 \mu \mathrm{g} \mathrm{L}^{-1}$, and $0.41-1.50 \mu \mathrm{g} \mathrm{L}^{-1}$, respectively. Cd contents in different seasons in both surface waters were in order of spring $<$ summer $<$ autumn. Cd contents in spring were conformed to the upper limit for Cd in Grade I $\left(1.0 \mu \mathrm{g} \mathrm{L}^{-1}\right)$ in Sea water quality standard (GB 3097-1997) of China, while for summer and autumn were Grade I or Grade II (5.0 $\mu \mathrm{g}$ $\mathrm{L}^{-1}$ ). The pollution level of Cd in Jiaozhou Bay was very lightly in 1983. Maritime transport and the input from head of the island were the two major sources; stream flow discharge and overland runoff were also responsible.
\end{abstract}

\section{Introduction}

Heavy metal is one of the serious environmental issues in the world. Marine environment has been long suffering from anthropogenic pollution due to the environmental protection was lagging from the rapid developing of agriculture, industry and urbanization [1]. Cd is one of the critical heavy metal with features of persistence, high toxicity, high mobility, etc., and has been highly concerned. Hence, understanding the content, pollution level and source in marine environment is essential to environmental protection and pollution control [2-5].

Jiaozhou Bay is a semi-closed bay located in the south of Shandong Province, eastern China $\left(35^{\circ} 55^{\prime}-36^{\circ} 18^{\prime} \mathrm{N}, 120^{\circ} 04^{\prime}-120^{\circ} 23^{\prime} \mathrm{E}\right)$. The Bay is surrounded by Qingdao City, Jiaozhou City and Jiaonan City, in the west, north and south, and is connected to the Yellow Sea in the south. The total area, average water depth and bay mouth width are $446 \mathrm{~km}^{2}, 7 \mathrm{~m}$ and $3 \mathrm{~km}$, respectively. This bay has more than ten inflow rivers, including Haibo Rriver, Licun Rriver, Dagu Rriver, Loushan Rriver etc., all of which are seasonal rivers [6]. Previous studies showed that this bay had been polluted by various pollutants [3-6].

An investigation on Cd in surface waters in Jiaozhou Bay was carried on in May, September and October in 1983. The aim of this paper was to analyze the content, distribution and source of $\mathrm{Cd}$, to provide basic information for Cd pollution at the initial stage of Chinese reform and opening up, and to provide basis for pollution control. 


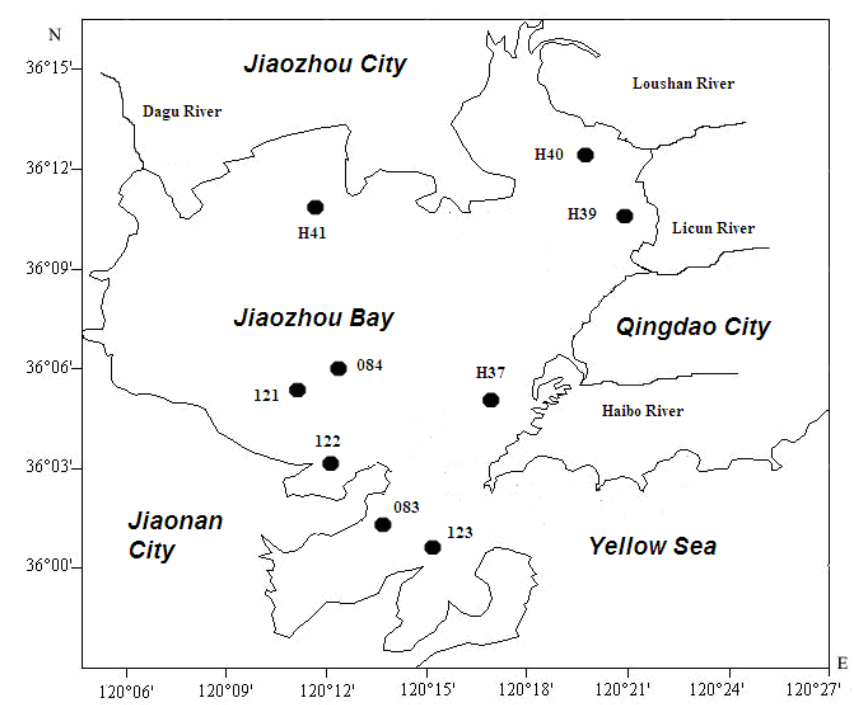

Fig. 1 Geographical location and monitoring sites of Jiaozhou Bay

\section{Contents and pollution level}

Cr content in May, September and October in surface water in Jiaozhou Bay ranged from 0.09-0.41 $\mu \mathrm{g} \mathrm{L}^{-1}, 0.40-3.33 \mu \mathrm{g} \mathrm{L}^{-1}$, and 0.41-1.50 $\mu \mathrm{g} \mathrm{L}^{-1}$, respectively. We defined April, September and October as the representatives of spring, summer and autumn, respectively. Cd contents in different seasons in surface waters were in order of spring $<$ summer $<$ autumn. Cd contents in spring were conformed to the upper limit for Cd in Grade I $\left(1.0 \mu \mathrm{g} \mathrm{L}^{-1}\right)$ in Sea water quality standard (GB 3097-1997) of China, while for summer and autumn were Grade I or Grade II (5.0 $\mu \mathrm{g}$ $\mathrm{L}^{-1}$ ). It could be concluded that the pollution level of Cd in Jiaozhou Bay was very lightly in 1983.

\section{Distribution of Cd}

The horizontal distributions of Cd in surface water in May, Septemer and October were showed in Fig. 2, Fig. 3 and Fig. 4, respectively. In May, a relative high value $\left(0.37 \mu \mathrm{g} \mathrm{L}^{-1}\right)$ was occurred in Site H37 in coastal water in the north of the bay, and were forming a serious of concentric circles which were decreasing gradiently from the west to the northwest (Fig. 2). Meanwhile, there was a high value $\left(0.41 \mu \mathrm{g} \mathrm{L}^{-1}\right)$ outside the bay mouth in Site H34, and were forming a serious of concentric circles which were decreasing gradiently from the high value center to the southeast (Fig. 2). In September, a relative high value $\left(0.33 \mu \mathrm{g} \mathrm{L}^{-1}\right)$ was occurred in Site H36 closed to the head of the island, and were forming a serious of concentric circles which were decreasing gradiently from the bay mouth to the north, as well as decreasing gradiently from to the east outside the bay mouth (Fig. 3). In October, a relative high value $\left(0.80 \mu \mathrm{g} \mathrm{L}^{-1}\right)$ was occurred in Site H38 between the estuaries of Licun River and Loushan River in the northeast of the bay. Another high value center $\left(1.50 \mu \mathrm{g} \mathrm{L}^{-1}\right)$ were in the estuary of Haibo River in Site H37, and were forming a serious of concentric circles which were decreasing gradiently from the high value center to the north of the bay, as well as waters outside the bay mouth (Fig. 4). The different horizontal distributions of $\mathrm{Cr}$ in surface waters in different seasons indicated that there might be various sources of Cr. 


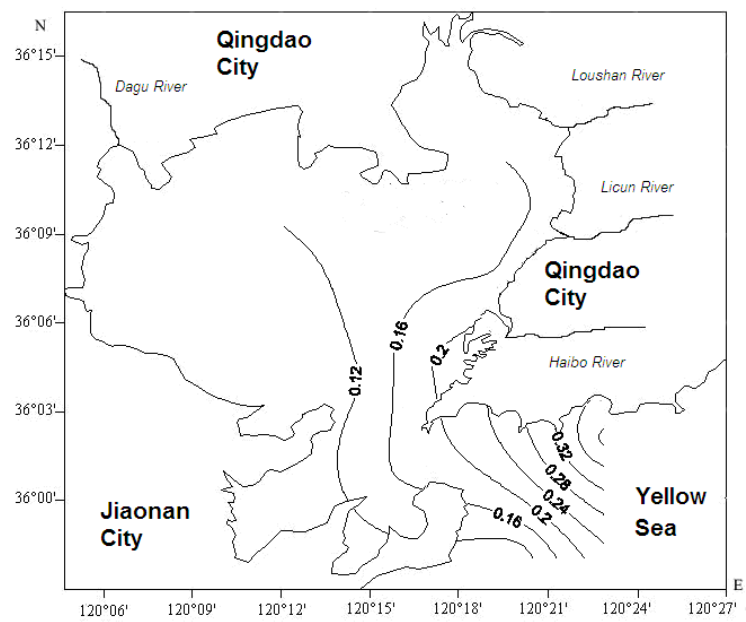

Fig. 2 Distributions of Cr in surface in May in Jiaozhou Bay/ $\mu g \mathrm{~L}^{-1}$

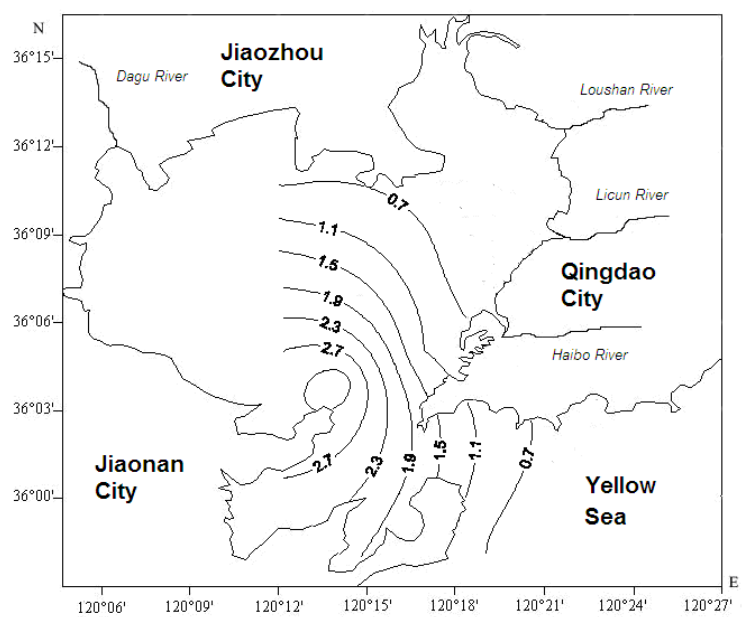

Fig. 3 Distributions of $\mathrm{Cr}$ in surface in September in Jiaozhou Bay/ $\mu \mathrm{g} \mathrm{L}^{-1}$

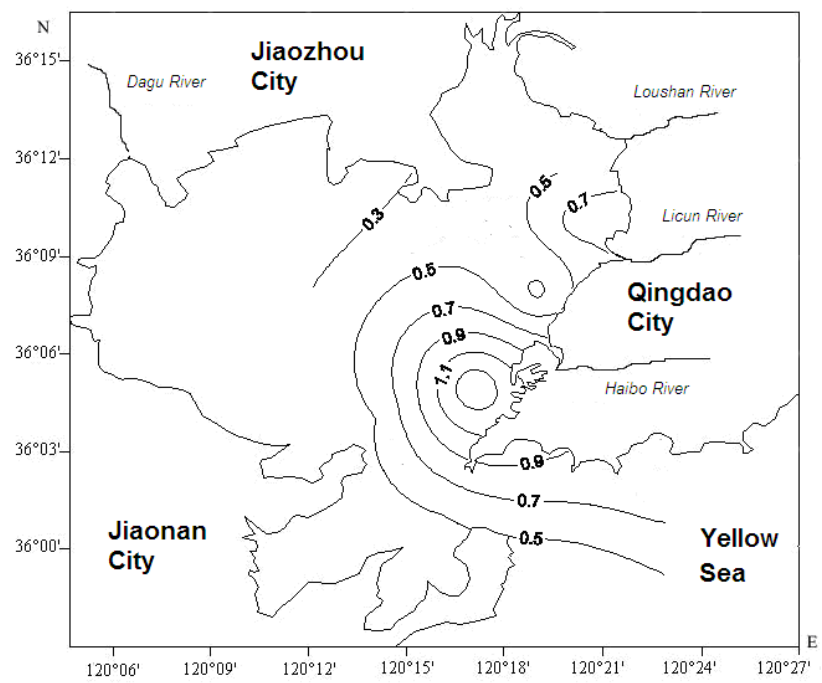

Fig. 4 Distributions of Cr in surface in October in Jiaozhou Bay/ $\mu g \mathrm{~L}^{-1}$

\section{Source of Cd}

$\mathrm{Cd}$ in the bay could be inputted by sources of stream flow discharge, maritime transport, overland runoff etc. A high value region was occurred in May in outside the bay mout, in where were the major port and water channel. Hence, it could be defined that maritime transport was one of the pollution source. High value region was occurred closed to the head of the island in 
September, indicated that the input from head of the island was responsible. High value region were occurred in waters between the estuaries of Loushan River and Licun River in October, indicated stream flow discharge was the major source. In generally, the major Cr sources in Jiaozhou Bay stream flow discharge, maritime transport, input from head of the island, and overland runoff, whose source strengths were $0.80 \mu \mathrm{g} \mathrm{L}^{-1}, 1.50 \mu \mathrm{g} \mathrm{L}^{-1}, 3.33 \mu \mathrm{g} \mathrm{L}^{-1}$ and $0.41 \mu \mathrm{g} \mathrm{L}^{-1}$, respectively.

\section{Conclusion}

The pollution level of Cd in Jiaozhou Bay was lightly in 1983. The major sources of Cr were stream flow discharge, maritime transport, input from head of the island, and overland runoff, whose source strengths were $0.80 \mu \mathrm{g} \mathrm{L}^{-1}, 1.50 \mu \mathrm{g} \mathrm{L}^{-1}, 3.33 \mu \mathrm{g} \mathrm{L}^{-1}$ and $0.41 \mu \mathrm{g} \mathrm{L}^{-1}$, respectively.

\section{Acknowledgement}

This research was sponsored by Education Ministry's New Century Excellent Talents Supporting Plan (NCET-12-0659), Project of Outstanding Technological Educators of Governor of Guizhou ([2012]71), Project of Low Carbon Technology Plan of Guiyang (2012205]), Project of Science and Technology Foundation of Guiyang (LKM[2012]05), Special Research Projects of High Level Talents of Guizhou Province (TZJF-2011-44), Research Projects of Guizhou Nationalities University ([2014]02), Science and Technology Research Projects of Education Office of Guizhou Province ([2014]266), Science and Technology Research Projects of Science and Technology Agency of Guizhou Province ([2014]7376), and Director Fund projects of North China Sea Environmental Monitoring Center, State Ocean Administration (05EMC16).

\section{References}

[1] Yang DF and Miao ZQ: Marine Bay Ecology (I): Beijing, Ocean Precess, (2010), p. 1-320. (in Chinese)

[2] Yang DF, Chen Y, Wang H, et al.: Coastal Engineering, Vol. 29 (2010), p. 73-82.

[3] Yang DF, Chen Y, Liu CX, et al.: Coastal Engineering, Vol. 32(2013), p. 68-78.

[4] Yang DF, Zhu SX, Wu YF, et al.: Applied Mechanics and Materials, Vols.644-650 (2014), p. 5325-5328.

[5] Yang DF, Wang FY, Wu YF, et al.: Applied Mechanics and Materials, Vols.644-650 (2014), p. 5329-5312.

[6] Yang DF. Chen Y, Gao ZH, et al.: Proceedings of the 2015 international symposium on computers and informatics, (2015), p. 2667-2674. 